Vol 7, No 2, Oktober 2012: $102-115$

\title{
PEMETAAN SIKAP DEMOKRATIS MAHASISWA BARU FAKULTAS ILMU SOSIAL DAN ILMU POLITIK UNIVERSITAS RIAU TAHUN 2012
}

\author{
Adlin $^{1}$ dan Syafri Harto ${ }^{2}$ \\ 1) Jurusan IImu Pemerintahan FISIP UNRI \\ 2)Jurusan Hubungan Internasional FISIP UNRI
}

\section{ABSTRAK}

Pendalaman sikap demokratis penting dalam upaya menwujudkan konsolidasi demokrasi di Indonesia. Salah satu syarat pendukung konsolidasi adalah terinternalisasi sikap politik demokratis di kalangan elit, maupun masyarakat dan mahasiswa. Dewasa ini aksi politik mahasiswa tidak hanya berlangsung secara damai namun kadangkala juga diakhiri oleh aksi anarkis. Mahasiswa baru FISIP angkatan 2012 perlu dipetakan sikap demokratisnya agar bisa dibina dalam rangka mewujudkan insan yang berkualitas dan bermanfaat bagi pengembangan konsolidasi demokrasi di Indonesia. Menurut Osterich sikap demokratis generasi muda dapat diukur dengan 5 indikator yaitu komitmen untuk melakukan kewajiban demokrasi, melakukan kegiatan politik konvensional, melakukan kegiatan sosial, melakukan protes secara damai dan komitmen melakukan kegiatan politik non konvensional. Penelitian ini menggunakan metode kuantitatif dengan teknik systematic random sampling sehingga didapatkan 83 responden. Data diambil melalui kuesioner tertutup yang selanjutnya dianalisa dan ditampilkan dalam bentuk Tabel frekuensi dan Tabel silang. Hasil penelitian menunjukkan mayoritas responden berkomitmen untuk melakukan kegiatan politik konvensional berupa menulis tentang permasalahan sosial di media massa dan menunaikan kewajiban demokratis berupa ikut serta dalam pemilihan umum.

Kata kunci : mahasiswa baru, sikap demokratis

\section{PENDAHULUAN}

Proses transisi demokrasi di Indonesia yang dimulai sejak tahun 1998 diharapkan akan mencapai tahap konsolidasi demokrasi. Namun pengalaman negara-negara Amerika latin menunjukkan bahwa tidak semua proses transisi menuju demokrasi menghasilkan output berupa berjalannya sistem demokrasi secara mapan atau dapat dikatakan negara yang demokrasinya belum terkonsolidasi (Rafiudin, 2011). Indonesia pasca orde baru masih mengalami berbagai masalah dan dapat dikategorikan sebagai negara dengan demokrasi belum terkonsolidasi 
yang ditandai dengan praktek demokrasi yang dijalankan masih jauh dari nilai-nilai demokrasi ideal seperti yang ditunjukkan oleh negara Jepang dan negara-negara eropa barat (Rafiudin, 2011).

Salah satu bentuk perilaku tidak demokratis yang selama ini sering terjadi adalah partisipasi dan penyampaian aspirasi warga negara melalui cara-cara yang anarkis. Presiden SBY menyatakan keprihatinannya mengenai maraknya aksi anarkis disebabkan ketidakpahaman warga negara dalam menyampaikan aspirasi di era demokrasi (http://www.republika.co.id/berita/nasional/politik/12/02/24, akses 15 September 2012). Sementara itu, Ikrar Nusa Bhakti melihat bahwa sebagian besar demonstrasi yang sedang terjadi berjalan secara damai, walau ada juga yang anarkis seperti yang terjadi di Makassar, namun tentunya langkah mahasiswa yang menutup Pom Bensin di Cikini, Jakarta, membagi-bagikan tabung gas berisi dan Air Minum kemasan di Makassar, menyetop, menendang dan bahkan ada yang membakar kendaraan yang mereka hentikan di Makassar, adalah perbuatan yang anarkis dan melawan hukum (http://web.inilah.com/read/detail/1844601/ menghindari-demonstrasi-anarkis, akses 15 September 2012). Sejalan dengan itu Hasse $J$ (2012) juga menulis bahwa demonstrasi yang dilakukan oleh mahasiswa khususnya di makassar (hampir selalu) berujung kekerasan bahkan pola dan kecendrungan kekerasan relatif sama. Aksi-aksi yang dilakukan selama ini menunjukkan kekurangdewasaan dalam menyampaikan aspirasi, cenderung melawan hukum dan menyimpang dari etika moralitas.

Aksi demonstrasi mahasiswa di pekanbaru, yang kadangkala melibatkan mahasiswa Fakultas IImu Sosial dan IImu Politik Universitas Riau sebagian besar berlangsung secara damai dan masih berjalan dalam koridor demokrasi. Namun ada juga yang diiringi tindakan anarkis, misalnya mahasiswa merusak tugu PON seharga 1,3 Milyar di Jalan Kartini Pekanbaru, yang diduga pembangunannya sarat korupsi (http://news.okezone.com/read/2012/05/23/mahasiswa-riau-rusak-tugu-pon-xviii, akses 18 September 2012). Demonstrasi elemen masyarakat dan mahasiswa dalam menolak kenaikan bahan bakar minyak di kontor DPRD Riau berakhir ricuh (http://www.zamrudtv.com/riau-4320-aksi-demo-mahasiswa-di-dprd-riau-berakhirricuh, akses 18 September 2012). Demo mahasiswa yang menuntut pengusutan kasus korupsi PON, diwarnai pelemparan telur busuk sebagai ungkapan kekecewaan terhadap keterlibatan anggota DPRD Riau dalam kasus korupsi 
Vol 7, No 2, Oktober 2012: $102-115$

(http://www.metrotvnews.com/ read/newsvideo/2012/06/12/Demo-Korupsi-PON-diGedung-DPRD-Riau-Ricuh, akses 18 September 2012)

Masih adanya demo mahasiswa yang kadangkala melibatkan mahasiswa FISIP Universitas Riau, maka dipandang perlu melakukan pemetaan komitmen mahasiswa FISIP dalam bersikap demokratis, khususnya mahasiswa baru FISIP tahun 2012. Pemetaan ini akan berguna untuk melihat bentuk-bentuk sikap mahasiswa yang dihubungkan dengan nilai-nilai demokratis dapat diketahui dari awal sehingga materi pendalaman nilai-nilai demokratis bagi mahasiswa dapat diberikan dapat sesuai dengan kondisi mahasiswa. Dengan demikian diharapkan mahasiswa baru FISIP dapat menjadi bagian penting dalam mewujudkan konsolidasi demokrasi di Indonesia.

Secara teoritis menurut Whitehead dalam Rafiudin (2011) konsolidasi demokrasi meliputi peningkatan secara prinsip terhadap bekerjanya demokrasi beserta seluruh aturan mainnya dan oleh seluruh masyarakat. Diamond dalam Rafiudin (2011) menyatakan salah satu indikator penting yang mendukung terwujudnya konsolidasi demokrasi di sebuah negara adalah terjadinya pendalaman demokrasi yang diwujudkan tingginya komitmen para aktor politik baik ditingkat elit maupun massa untuk berperilaku demokrasi sesuai aturan hukum di dalam konstitusi. Manakala pendalaman melemah, maka dapat disimpulkan pula konsolidasi demokrasi pun mengalami penurunan. Marijan (2010) menyatakan untuk membangun sistem politik yang demokratis juga memerlukan perbaikan budaya politik pada tingkat individu, baik pada tataran elit maupun massa yang meliputi sikap-sikap dan perilaku para aktor yang terlibat didalam sistem politik tersebut. Sejalan dengan itu, Oesterreich dalam Zajda (2009) sikap demokratis individu termasuk generasi muda dapat diukur dengan cara melihat sejauhmana komitmen mereka untuk melakukan aktivitas politik yang demokratis berdasarkan indikator :

1. Komitmen dalam melaksanakan kewajiban demokratis, yang diukur dengan kesediaan memilih dalam pemilu dan usahanya untuk mendapatkan informasi tentang kandidat sebelum menjatuhkan pilihan politik.

2. Komitmen untuk melakukan aktivitas politik konvensional berupa kesediaan bergabung dengan partai politik, membuat tulisan tentang masalah sosial dan politik di media massa, dan bersedia menjadi kandidat untuk memegang jabatan politik. 
3. Komitmen untuk melakukan kegiatan sosial berupa meluangkan waktu menjadi sukarelawan untuk membantu fakir miskin atau kaum kurang beruntung dan bersedia mengumpulkan uang untuk mendukung kegiatan sosial.

4. Komitmen melakukan protes secara damai berupa kesediaan mengumpulkan tanda tangan untuk mendukung sebuah petisi dan berpartisipasi dalam demonstrasi damai.

5. Kesediaan melakukan tindakan protes yang tidak sesuai aturan hukum seperti membuat tulisan di tembok atau dinding, memblokir jalan sebagai bentuk protes dan menduduki kantor milik pemerintah sebagai bentuk protes.

\section{METODE PENELITIAN}

Penelitian ini menggunakan menggunakan metode kuantitatif dengan pengambilan responden menggunakan teknik systematic random sampling. Pengambilan sampel dilakukan secara proporsional berdasarkan jumlah mahasiswa baru yang masuk pada masing-masing program studi dan jurusan di FISIP Universitas Riau. Berdasarkan data tersebut direncanakan menarik 100 orang responden, dengan derajat kepercayaan 95\%. Pengambilan data dilakukan dengan menyebarkan kuesioner kepada responden terpilih, namun disebabkan berbagai hal kuesioner yang kembali hanya sebanyak 83 kuesioner. Kemudian data yang terkumpul akan dianalisa melalui dengan menampilkan frekuensi data temuan penelitian dalam bentuk tabulasi tunggal dan tabulasi silang.

\section{HASIL DAN PEMBAHASAN}

Hasil penelitian menunjukkan bahwa tingkat sikap mahasiswa baru Fisip angkatan 2012 memiliki tingkat komitmen bersikap demokratis yang berbeda pada setiap indikator dari 5 indikator yang diujikan yang diuraikan sebagai berikut:

\section{A. Menunaikan Kewajiban Demokratis}

Menurut Oesterreich salah satu indikator yang dapat mengukur sikap demokratis generasi mudah adalah sejauh mana komitmen mereka dalam menunaikan kewajiban demokratis yang dapat diukur melalui komitmen mengikuti pemilihan umum dan kesediaan mencari informasi yang memadai tentang kandidat 
Vol 7, No 2, Oktober 2012: $102-115$

sebelum menjatuhkan pilihan. Adapun tingkat komitmen mahasiswa baru FISIP angkatan 2012 menunaikan kewajiban demokratis dapat diihat pada Tabel 1.

Tabel 1. Komitmen Untuk Menunaikan Kewajiban Demokratis

\begin{tabular}{|l|c|c|c|c|}
\hline \multicolumn{1}{|c|}{ Pertanyaan } & \multicolumn{3}{|c|}{ Jawaban } & $\begin{array}{c}\text { Total } \\
\text { (Jumlah/\%) }\end{array}$ \\
\cline { 2 - 5 } & $\begin{array}{c}\text { Ya } \\
\text { (Jumlah/\%) }\end{array}$ & $\begin{array}{c}\text { Tidak } \\
\text { (Jumlah/\% } \\
\text { ) }\end{array}$ & $\begin{array}{c}\text { Tidak } \\
\text { Jawab } \\
\text { (Jumlah/\%) }\end{array}$ & \\
\hline $\begin{array}{l}\text { 1. } \\
\text { Akan ikut memilih } \\
\text { dalam pemilu/pilkada } \\
\text { dibandingkan } \\
\text { mengikuti kegiatan } \\
\text { lain yang merupakan } \\
\text { kegiatan yang } \\
\text { digemari. }\end{array}$ & $54(65)$ & $28(34)$ & $1(1)$ & \\
\hline $\begin{array}{l}\text { Bersedia meluangkan } \\
\text { waktu dan bersusah } \\
\text { payah mencari } \\
\text { informasi tentang } \\
\text { kandidat sebelum } \\
\text { menentukan pilihan }\end{array}$ & $27(32,5)$ & $52(62,7)$ & $4(4,8)$ & \\
\hline
\end{tabular}

Sumber : Data Olahan.

Data dalam Tabel 1 menunjukkan bahwa peresentase mahasiswa yang komitmen mengikuti pemilu lebih tinggi (65\%) dibandingkan persentase mahasiswa yang tidak berkomitmen mengikuti pemilihan umum. Angka 65\% mahasiswa yang memiliki komitmen mengikuti pemilu sebenarnya merupakan angka yang kurang menggembirakan sebab dibawah angka partisipasi masyarakat secara nasional dalam pemilihan presiden tahun 2009 yang mencapai angka 70,9\%. Menurut Budiardjo (2008), angka partisipasi politik secara nasional dalam pemilu memang cenderung menurun, namun hasil penelitian menunjukan tingkat komitmen masyarakat, khususnya mahasiswa baru FISIP angkatan 2012 semakin menurun dalam kesediaan menunaikan kewajiban demokratis. Padahal menurut Rush \& Althoff (2007), kegiatan pemberian suara dapat dianggap sebagai bentuk partisipasi politik yang paling rendah, yang menuntut keterlibatan minimal. Dengan demikian tingkat kesediaan mahasiswa FISIP untuk ikut kegiatan pemilu lebih rendah dibandingkan angka keikutsertaan masyarakat indonesia untuk memilih dalam pemilu. Penelitian ini menunjukkan bahwa sebagian mahasiswa baru FISIP lebih berkomitmen untuk melakukan kegiatan lainnya dibandingkan berpartisipasi dalam Pemilu. Rendahnya komitmen berpartisipasi dalam Pemilu akan membuat jumlah 
pemilih yang tidak menggunakan hak pilinnya (golput) akan semakin meningkat dari tahun ke tahun.

Data dalam Tabel 1 juga menunjukkan bahwa komitmen responden untuk meluangkan waktu mencari informasi tentang kandidat lemah $(32,5 \%)$. Hal ini menggambarkan bahwa sangat sulit mengharapkan responden untuk menentukan pilihan dalam pemilu secara rasional atau memilih calon yang paling menguntungkan bagi kemajuan masyarakat diantara kandidat yang tersedia. Sebab untuk dapat memilih secara rasional, seorang pemilih harus mendapatkan informasi yang benar dan tepat (fully informed). Sikap responden yang demikian akan membuat responden memilih secara tidak akurat, sehingga membuka ruang bagi terpilihnya kandidat pemegang jabatan politik yang tidak bisa menjalankan tugasnya, akibatnya pelaksanaan pemerintahan dan pembangunan tidak dapat berjalan sebagaimana mestinya. Di era sekarang, berbagai sumber informasi dapat dimanfaatkan untuk mengetahui berbagai informasi tentang calon yang menjadi kandidat peserta Pemilu, antara lain melalui media surat kabar, televisi, media luar ruang dan internet. Berbagai media ini menyediakan berbagai informasi tentang kandidat baik yang positif maupun negatif dan dapat dimanfaatkan pemilih dalam menjatuhkan pilihannya secara tepat dalam pemilu. Pada saat media informasi sudah tersedia, maka yang dibutuhkan adalah komitmen masyarakat, termasuk mahasiswa untuk mencari informasi dan memanfaatkan informasi tersebut dalam mempertimbangkan berbagai calon yang ada dan selanjutnya memilih terbaik bagi kemajuan masyarakat.

Data Tabel 1 juga menunjukkan bahwa komitmen mencari informasi tentang kandidat sebelum melakukan pemilihan lebih rendah dibandingkan komitmen untuk mengikuti pemilihan umum. Hal ini ini menunjukkan bahwa responden hanya berkomitmen untuk melaksanakan kewajiban demokrasi secara prosedural, sebagai kegiatan seremonial atau rutinitas namun minim substansi nilai-nilai yang diharapkan dalam praktek demokrasi. Padahal substansi terpenting yang diharapkan sebagai output Pemilu adalah terpilihnya pemimpin-pemimpin politik yang berkualitas dan mampu mensejahterakan masyarakat. Pemimpin yang berkualitas tidak akan pernah dihasilkan dalam sebuah pemilu, jika para pemilihnya tidak berusaha mencari informasi yang lengkap dan menjatuhkan pilihan pada calon yang berkualitas tersebut. Kondisi ini akan membuat pemimpin-pemimpin politik yang akan terpilih adalah pemimpin yang kurang tepat serta tidak mampu mensejahterakan 
Vol 7, No 2, Oktober 2012: $102-115$

masyarakat sehingga kondisi kesejahteraan masyarakat tidak meningkat secara signifikan. Artinya terpilihnya pejabat kurang berkualitas akan berakibat pada stagnannya kemajuan bangsa dan hal tersebut terjadi disebabkan kelalaian pemilih dalam menentukan pilihannya dalam pemilu. Oleh karena itu diperlukan usaha lebih keras untuk memberi pemahaman kepada mahasiswa, bahwa usaha mencari informasi tentang kandidat pemimpin politik sebelum menjatuhkan pilihan dalam pemilu sangat penting agar pemilu yang dilaksanakan menghasilkan pemimpinpemimpin yang tepat sehingga kesejahteraan rakyat secara bertahap dapat diwujudkan.

\section{B. Komitmen aktif dalam kegiatan politik konvensional}

Keikutsertaan generasi muda dalam kegiatan politik konvensional penting dalam pembangunan demokrasi. Berikut ini digambarkan komitmen mahasiswa baru dalam mengikuti kegiatan politik konvensional Tabel 2.

Tabel 2. Komitmen Aktif Dalam Kegiatan Politik Konvensional

\begin{tabular}{|c|c|c|c|c|}
\hline \multirow[t]{2}{*}{ Pertanyaan } & \multicolumn{3}{|c|}{ Jawaban } & \multirow{2}{*}{$\begin{array}{c}\text { Total } \\
\text { (Jumla } \\
\text { h/\%) }\end{array}$} \\
\hline & $\begin{array}{c}\text { Ya } \\
\text { (Jumlah/\%) }\end{array}$ & $\begin{array}{c}\text { Tidak } \\
\text { (Jumlah/\%) }\end{array}$ & $\begin{array}{c}\text { Tidak Jawab } \\
\text { (Jumlah/\%) }\end{array}$ & \\
\hline $\begin{array}{l}\text { 1. Bersedia menulis surat } \\
\text { kepada media tentang } \\
\text { masalah sosial atau } \\
\text { politik }\end{array}$ & $62(75)$ & $20(24)$ & $1(1)$ & $83(100)$ \\
\hline $\begin{array}{l}\text { 2. Berminat menjadi } \\
\text { anggota DPRD atau } \\
\text { jabatan politik lainnya }\end{array}$ & $44(53)$ & $37(45)$ & $2(2)$ & $83(100)$ \\
\hline $\begin{array}{l}\text { 3. Bersedia bergabung } \\
\text { sebagai anggota/ } \\
\text { pengurus partai politik } \\
\text { di tingkat desa atau } \\
\text { lebih tinggi. }\end{array}$ & $35(42)$ & $45(54)$ & $3(4)$ & $83(100)$ \\
\hline
\end{tabular}

Sumber : Data Olahan.

Berdasarkan Tabel 2 dapat dilihat bahwa mayoritas (75\%) responden mempunyai komitmen untuk menulis surat kepada media tentang masalah sosial atau politik. Mengirimkan tulisan berupa surat pembaca, mengisi kolom opini maupun bentuk lain berupa mengirimkan short message service kepada media massa penting dalam rangka menyampaikan aspirasi kepada pemerintah agar pemerintah membuat kebijakan-kebijakan yang mengarah pada upaya mensejahterakan masyarakat. Media massa saat ini telah menjadi kekuatan politik yang mampu mempengaruhi kebijakan pemerintah. Sebab informasi yang disampaikan media 108 
massa akan mempengaruhi fikiran masyarakat secara luas dan akan berdampak terhadap penilaian masyarakat terhadap kinerja pemerintah. Jika pemerintah tidak kunjung memberikan respon terhadap aspirasi masyarakat yang dimuat melalui media, maka akan muncul keresahan dan tuntutan masyarakat yang lebih massif kepada pemerintah dan kadangkala dapat menjatuhkan pemerintah yang sedang berkuasa. Oleh karena itu aspirasi yang disampaikan melalui media akan menjadi perhatian pemerintah untuk diagendakan dalam pembuatan kebijakan sehingga kebijakan yang diputuskan akan lebih memihak kepada kepentingan rakyat. Disisi lain upaya menyampaikan informasi melalui media dapat dilihat sebagai sebuah upaya untuk mencerdaskan khalayak pembaca dan sebagai ajang pembelajaran bagi mahasiswa sebagai salah satu aktor nantinya akan dipercaya untuk menyampaikan aspirasi masyarakat. Tingginya komitmen responden menulis di media massa diharapkan menjadi kenyataan sehingga kedepan aspirasi mahasiswa sebagai penyampai suara rakyat diakomodasi oleh pemerintah dalam kebijakan yang dibuat.

Data dalam Tabel 2 juga menunjukkan bahwa lebih dari setengah responden berminat menduduki jabatan-jabatan politik misalnya menjadi anggota dewan perwakilan rakyat daerah atau pun jabatan politik. Minat ini menjadi penting, sebab menurut Pippa Norris, untuk menghasilkan pejabat politik yang berkualitas diperlukan sejumlah orang berminat. Semakin banyak orang yang berminat semakin baik, sebab semakin banyak calon diseleksi dan dari seleksi tersebut akan muncul kandidat-kandidat terbaik yang akan menjadi pilihan bagi masyarakat. Rendahnya partisipasi politik, salah satu penyebabnya calon yang ditampilkan partai politik kurang menarik dipilih menurut masyarakat, sebab calon diminati masyarakat tidak berminat mencalonkan diri melalui partai untuk menduduki jabatan politik.

Namun minat responden untuk bergabung dengan partai politik rendah. Menurut Wollack (2002), salah satu penyebabnya adalah citra partai politik di mata masyarakat kurang baik, partai dinilai korup, personalistis dan jauh dari aspirasi masyarakat. Citra partai semakin negatif dimata masyarakat juga disebabkan perilaku kader partai politik yang menjadi anggota legislatif yang terlalu lemah, bersifat membela kepentingan partai dan mempunyai jarak yang lebar dari aspirasi masyarakat. Walaupun demikian minat responden untuk bergabung ke dalam partai politik perlu didorong, sebab tidak mungkin responden menjadi anggota DPRD tanpa 
Vol 7, No 2, Oktober 2012: $102-115$

menjadi anggota atau pengurus partai politik. Dalam tradisi pemilu yang demokratis, partai politik diberi wewenang sebagai satu-satunya lembaga yang berhak mengusulkan orang untuk menjadi anggota DPRD melalui proses pemilihan umum. Oleh karena itu mahasiswa perlu di dorong masuk ke partai politik dalam rangka belajar dan pada saatnya nanti dapat menggantikan kader-kader yang kurang berkompeten sehingga partai politik akan membaik, sebab di isi oleh kader-kader yang memiliki kadar intelektual memadai di bidang sosial dan politik.

\section{Komitmen Melakukan Kegiatan Sosial}

Komitmen responden untuk melakukan kegiatan sosial bagian penting dari sikap demokratis. Adapun komitmen mahasiswa baru dalam melakukan kegiatan sosial dapat dilihat pada Tabel 3.

Tabel 3. Komitmen Melakukan Kegiatan Sosial

\begin{tabular}{|c|c|c|c|c|}
\hline \multirow[b]{2}{*}{ Pertanyaan } & \multicolumn{3}{|c|}{ Jawaban } & \multirow[b]{2}{*}{$\begin{array}{c}\text { Total } \\
\text { (Jumlah/\%) }\end{array}$} \\
\hline & $\begin{array}{c}\text { Ya } \\
\text { (Jumlah/\%) }\end{array}$ & $\begin{array}{c}\text { Tidak } \\
\text { (Jumlah/\%) }\end{array}$ & $\begin{array}{c}\text { Tidak } \\
\text { Jawab } \\
\text { (Jumlah/\%) }\end{array}$ & \\
\hline $\begin{array}{l}\text { 1. Bersedia dan sudah } \\
\text { terbiasa } \\
\text { mengumpulkan } \\
\text { koin/uang untuk } \\
\text { mendukung kegiatan } \\
\text { sosial }\end{array}$ & $48(58)$ & $33(40)$ & $2(2)$ & $83(100)$ \\
\hline $\begin{array}{l}\text { 2. Bersedia dan sudah } \\
\text { biasa menjadi } \\
\text { sukarelawan } \\
\text { membantu kaum } \\
\text { miskin }\end{array}$ & $47(57)$ & $35(42)$ & 1(1) & $83(100)$ \\
\hline
\end{tabular}

\section{Sumber : Data Olahan.}

Berdasarkan Tabel 3 dapat dilihat bahwa lebih dari setengah responden berkomitmen untuk melakukan kegiatan sosial berupa mengumpulkan koin/ uang untuk mendukung kegiatan sosial (58\%). Komitmen yang tinggi dalam mendukung kegiatan-kegiatan sosial menunjukkan tingginya kepedulian terhadap hak asasi manusia, berupa hak untuk hidup layak dan bentuk hak asasi lainnya. Adapun penghargaan terhadap hak asasi manusia adalah salah satu pilar yang harus ditegakkan di sebuah negara yang menganut paham demokrasi. Bahkan dewasa ini kegiatan mengumpulkan koin pada kasus-kasus tertentu menjadi simbol perlawanan terhadap ketidakadilan yang diterima oleh berbagai kalangan di masyarakat, misalnya kegiatan mengumpulkan koin untuk Prita, kegiatan mengumpulkan sandal 
bekas untuk polisi pelaku pemukulan terhadap anak-anak yang sinyalir mencuri sandal polisi tersebut. Komitmen yang tinggi dalam mengumpulkan koin dapat mendukung upaya tercapainya konsolidasi demokrasi di Indonesia.

Data dalam Tabel 3, juga menunjukkan bahwa komitmen mahasiswa untuk menjadi sukarelawan membantu orang miskin juga cukup tinggi (57\%). Komitmen ini juga berhubungan dengan dukungan untuk melakukan perlindungan hak asasi manusia, dalam hal ini memberikan dukungan bagi orang-orang miskin dan kurang beruntung. Selama ini komitmen membantu kaum yang kurang beruntung terlihat cukup aktif di kalangan mahasiswa FISIP universitas Riau, yang ditunjukkan dengan cukup maraknya kegiatan berbagai bantuan kepada panti jompo, anak-anak yatim piatu dan lain sebagainya. Tingginya komitmen mahasiswa baru dalam melakukan kegiatan-kegiatan sosial diharapkan dapat diaplikasikan dalam bentuk tingginya aktifitas berbagai elemen kemahasiswaan dalam melakukan berbagai kegiatan sosial bagi kaum yang kurang beruntung dari tahun ke tahun.

\section{Komitmen Melakukan Protes Secara Damai}

Tabel 4. Komitmen Melakukan Protes Secara Damai

\begin{tabular}{|c|c|c|c|c|}
\hline \multirow[t]{2}{*}{ Pertanyaan } & \multicolumn{3}{|c|}{ Jawaban } & \multirow{2}{*}{$\begin{array}{c}\text { Total } \\
\text { (Jumlah/\%) }\end{array}$} \\
\hline & $\begin{array}{c}\text { Ya } \\
\text { (Jumlah/\%) }\end{array}$ & $\begin{array}{c}\text { Tidak } \\
\text { (Jumlah/\%) }\end{array}$ & $\begin{array}{c}\text { Tidak } \\
\text { Jawab } \\
\text { (Jumlah/\%) }\end{array}$ & \\
\hline $\begin{array}{l}\text { 1. Bersedia } \\
\text { membubuhkan/ } \\
\text { mengumpulkan } \\
\text { tanda tangan } \\
\text { sebagai bentuk } \\
\text { penyampaian } \\
\text { aspirasi pada } \\
\text { pihak terkait }\end{array}$ & $55(63)$ & $27(33)$ & 1(1) & $83(100)$ \\
\hline $\begin{array}{l}\text { 2. Bersedia dan } \\
\text { berkeinginan } \\
\text { melakukan } \\
\text { demonstrasi } \\
\text { damai sebagai } \\
\text { bentuk protes } \\
\text { kepada pihak } \\
\text { terkait. }\end{array}$ & $44(53)$ & $38(46)$ & $1(1)$ & $83(100)$ \\
\hline
\end{tabular}

Sumber : Data Olahan.

Protes secara damai masih merupakan bentuk partisipasi politik konvensional atau sesuai dengan aturan hukum dan partisipasi politik jenis ini penting untuk pengembangan demokrasi di Indonesia yang sedang mengalami masa transisi 111 
Vol 7, No 2, Oktober 2012: $102-115$

menuju konsolidasi. Adapun komitmen responden untuk melakukan aksi protes secara damai dapat dilihat pada Tabel 4.

Berdasarkan data dalam Tabel 4 dapat diketahui bahwa komitmen melakukan aksi protes secara damai cukup tinggi baik berupa kesediaan ikut serta dalam kegiatan membubuhkan tanda tangan sebagai bentuk penyampaikan aspirasi kepada pihak terkait (63\%) maupun komitmen untuk melakukan demonstrasi secara damai (53\%). Kegiatan protes secara damai adalah salah satu bentuk partisipasi politik dan menurut Paige dalam Surbakti (1999), partisipasi politik berhubungan dengan tingkat kesadaran politik dan tingkat kepercayaan pada pemerintah, partisipasi politik aktif akan terjadi ketika kesadaran politik masyarakat tinggi dan tingkat kepercayaan kepada pemerintah juga tinggi. Komitmen mahasiswa untuk melalukan protes secara damai menunjukkan bahwa mahasiswa masih mempunyai tingkat kepercayaan yang tinggi kepada pemerintah. Artinya mahasiswa baru masih meyakini dengan cara-cara damai tanpa aksi anarkis, pemerintah akan mendengarkan dan mempertimbangkan aspirasi mereka dalam pembuatan kebijakan pemerintah.

Data pada Tabel 4 juga menggambarkan bahwa bahwa komitmen melakukan aksi protes secara damai berupa kesediaan ikut serta dalam kegiatan membubuhkan tanda tangan sebagai bentuk penyampaikan aspirasi kepada pihak terkait $(63 \%)$ lebih tinggi dibandingkan komitmen untuk melakukan demonstrasi secara damai (53\%). Hal ini menunjukkan bahwa mahasiswa baru masih percaya bahwa aksi mengumpulkan tanda tangan untuk mendukung tuntutan tertentu masih layak untuk dilakukan dan cukup efektif untuk mengingat pemerintah. Disisi yang lain, dapat dimaklumi bahwa kegiatan mengumpulkan tanda tangan lebih minim resiko dibandingkan mengikuti turut serta dalam kegiatan demostrasi turun ke jalan. Kegiatan demonstrasi mahasiswa akhir-akhir ini pada awalnya berlangsung damai kemudian disebabkan berbagai hal sering juga diakhiri dengan bentrok dengan aparat keamanan yang menyebabkan korban-korban di pihak mahasiswa. Hal ini tentu akan menjadi pertimbangan bagi responden sehingga komitmennya untuk melakukan protes secara damai agak menurun dibandingkan kegiatan mengumpulkan tanda tangan sebagai bentuk dukungan.

Selanjutnya komitmen mahasiswa baru untuk melakukan aksi protes secara damai ini perlu dikembangkan, sebab kekuasaan pemerintahan berpotensi sering diselewengkan dalam bentuk pembuatan kebijakan yang jauh dari harapan 112 
masyarakat. Oleh karena itu, pemerintah yang menjalankan kekuasaan dalam negara demokrasi harus selalu diawasi dan dingatkan oleh masyarakat agar selalu membuat kebijakan yang berpihak kepada rakyat dengan cara masyarakat perlu menyampaikan aspirasi atau tuntutan kepada pemerintah. Apabila masyarakat tidak menyampaikan aspirasi maka pemerintah mengganggap masyarakat setuju dengan semua kebijakan yang tetapkan oleh pemerintah. Dengan demikian aspirasi masyarakat harus disampaikan oleh mahasiswa agar kebijakan yang dibuat pemerintah semakin dekat dan menyentuh kebutuhan rakyat.

\section{E. Komitmen Melakukan Protes Tidak Sesuai Aturan Hukum}

Di kalangan mahasiswa juga cenderung berkembang aktivitas protes yang tidak sesuai dengan aturan hukum. Hal ini tidak terlepas dari respon aparat keamanan dan aparatur pemerintah yang cenderung tidak simpatik dengan aksi-aksi demonstrasi yang dilakukan oleh mahasiswa. Di sisi lain tidak dapat dipungkiri ada oknum mahasiswa yang cenderung menyampaikan aspirasi secara anarkis. Adapun komitmen responden untuk melakukan aksi protes yang tidak sesuai dengan aturan hukum dapat dilihat pada Tabel 5.

Data pada Tabel 5 menunjukkan bahwa secara umum komitmen responden untuk melakukan aksi protes tidak sesuai aturan cenderung rendah. Bentuk kegiatan yang paling tinggi akan dilakukan responden adalah menyegel kantor pemerintahan, selanjutnya menulis slogan di tembok dan yang terakhir adalah memblokir jalan sebagai bentuk protes. Temuan ini cukup menggembirakan sebab aksi protes non konvensional kurang baik bagi pengembangan demokrasi dan konsolidasi demokrasi. Di negara yang belum mengalami konsolidasi, terjadi kecenderungan masyarakat untuk melakukan kegiatan politik non konvensional. Partisipasi politik yang bersifat radikal atau partisipasi politik militan radikal, menurut Paige dalam Surbakti (1999), terjadi ketika kesadaran politik aktor tinggi, sedangkan tingkat kepercayaan kepada pemerintah rendah. Dalam hal ini aktor melihat bahwa aksi radikal atau anarkis merupakan cara yang paling efektif untuk menekan pemerintah. Data ini kembali menunjukkan bahwa tingkat kepercayaan mahasiswa baru kepada pemerintah cukup tinggi. 
Vol 7, No 2, Oktober 2012: $102-115$

Tabel 5. Komitmen Melakukan Protes Tidak Sesuai Aturan Hukum

\begin{tabular}{|c|c|c|c|c|}
\hline \multirow[b]{2}{*}{ Pertanyaan } & \multicolumn{3}{|c|}{ Jawaban } & \multirow[b]{2}{*}{$\begin{array}{c}\text { Total } \\
\text { (Jumlah/\%) }\end{array}$} \\
\hline & $\begin{array}{c}\text { Ya } \\
\text { (Jumlah/\%) }\end{array}$ & $\begin{array}{c}\text { Tidak } \\
\text { (Jumlah/\%) }\end{array}$ & $\begin{array}{c}\text { Tidak } \\
\text { Jawab } \\
\text { (Jumlah/\%) }\end{array}$ & \\
\hline $\begin{array}{l}\text { 1. Jika perlu, } \\
\text { bersedia } \\
\text { menyegel atau } \\
\text { menduduki } \\
\text { kantor tertentu } \\
\text { yang kurang } \\
\text { peduli dengan } \\
\text { aspirasi banyak } \\
\text { orang }\end{array}$ & $28(34)$ & $53(64)$ & $2(2)$ & $83(100)$ \\
\hline $\begin{array}{l}\text { 2. Berbakat } \\
\text { menulis slogan } \\
\text { di tembok/ } \\
\text { dinding sebagai } \\
\text { bentuk protes. }\end{array}$ & $14(17)$ & $68(82)$ & $1(1)$ & $83(100)$ \\
\hline $\begin{array}{l}\text { 3. Jika perlu, } \\
\text { bersedia } \\
\text { memblokir jalan } \\
\text { sebagai bentuk } \\
\text { protes kepada } \\
\text { pihak tertentu. }\end{array}$ & $12(15)$ & $70(84)$ & $1(1)$ & $83(100)$ \\
\hline
\end{tabular}

Sumber : Data Olahan.

Walau bagaimanapun bentuk protes-protes non konvensional yang dilakukan oleh mahasiswa perlu dikurangi, sebab masih ada bentuk-bentuk partisipasi politik lainnya yang lebih baik untuk dilakukan. Namun demikian, aksi anarkis yang tidak jarang menimbulkan korban di pihak mahasiswa muncul disebabkan rasa frustasi akibat cara-cara konvensional telah dilakukan tetapi tidak mendapatkan respon yang memadai dari pemerintah. Selanjutnya agar kegiatan politik non konvensional tidak meningkat, maka pemerintah perlu membina rasa saling percaya dengan masayarakat dan mahasiswa, dengan munculnya rasa saling percaya akan menyebabkan menurunnya aksi politik non konvensional sehingga negara menjadi aman dan demokrasi dapat terkonsolidasi di Indonesia. 


\section{KESIMPULAN}

Hasil penelitian menunjukkan bahwa mayoritas responden berkomitmen untuk bersikap demokratis. Mayoritas responden berkomitmen melakukan kegiatan politik non konvensional berupa berkomitmen menyampaikan aspirasi secara tertulis dimedia massa (75\%), di ikuti kesediaan untuk menunaikan kewajiban demokratis berupa ikut serta dalam pemilu (65\%). Selanjutnya mayoritas responden berkomitmen rendah untuk melakukan aktivitas politik non konvensional berupa menyegel kantor pemerintah, memblokir jalan dan menulis tulisan di tembok sebagai bentuk protes.

\section{DAFTAR PUSTAKA}

Budiardjo, Miriam ,2008.. Dasar-Dasar IImu Politik. Jakarta: PT. Gramedia Pustaka Utama

J, Hasse, 2012. Anarkisme Demonstrasi Mahasiswa: Studi Kasus Pada Universitas Islam Negeri Alauddin Makassar. Jurnal Studi Pemerintahan Vol.3 Nomor 1 tahun 2012.

Marijan, Kacung, 2010. Sistem Politik Indonesia: Konsolidasi Demokrasi Pasca-Orde Baru. Jakarta: Kencana.

Norris, Pippa (ed), 1997. Passage to Power : Legislative Recruitment in Advanced Democracies. Cambridge : Cambridge University Press.

Raffiudin, Riaty, 2011. Teori Politik. Jakarta: Universitas Terbuka.

Rush, Michael \& Althoff, Phillip, 2007. Pengantar Sosiologi Politik. Jakarta: PT. Raja Grafindo Persada.

Sahdan, Goergerius (2004). Jalan Transisi Demokrasi Pasca Soeharto. Bantul: Pondok Edukasi.

Surbakti, Ramlan ,1999. Memahami Ilmu Politik. Jakarta : Grasindo.

Zajda, J, et.al (eds), 2009. Nation-Building, Identity and Citizenship Education: Cross-Cultural Perspective, Globalisation, Comparative Education and Policy Research 3. Springer Science + Business Media B.V 2009. 